\title{
Revision of the genus Vanniusoides (Heteroptera: Miridae)
}

\author{
$J_{A C E K}$ GORCZYCA ${ }^{1}$ and FEDOR KONSTANTINOV ${ }^{2}$ \\ ${ }^{1}$ Department of Zoology, Silesian University, Bankowa 9, 40-007 Katowice, Poland; e-mail: gorczyca@us.edu.pl \\ ${ }^{2}$ Department of Entomology, Faculty of Biology \& Soil Sciences, St. Petersburg State University, Universitetskaya emb. 7/9, 199034 \\ St. Petersburg, Russia; e-mail: konst@ent.bio.pu.ru
}

Key words. Vanniusoides, Miridae, Heteroptera, revision, new species, entomology, Solomon Islands

\begin{abstract}
The genus Vanniusoides Carvalho \& Lorenzato is revised and redescribed, a new species $V$. clypeatus is described from the Solomon Islands. Redescription of the species $V$. brevis (Poppius) and a key to the species of the genus are given. Illustrations of dorsal habitus, tarsi and male genitalia of the new species are provided.
\end{abstract}

\section{INTRODUCTION}

The genus Vanniusoides was established (Carvalho \& Lorenzato, 1978) for a single species, Vannius brevis Poppius. This species from Papua New Guinea was described on the basis of a single female.

Originally, the new genus was distinguished from the genus Vannius Distant, 1883 by the presence of a small tubercle projecting downwards on the clypeus. Vannius Distant, Vanniusoides Carvalho \& Lorenzato and other related genera were grouped in the tribe Vanniini in the Palaucorinae (Gorczyca, 1997).

The genus Vanniusoides is known only from Papua New Guinea and distinguished from the other genera of the tribe by the pretarsal structure, structure of head, thin elongated femora and structure of male genitalia (Gorczyca, 1997).

During a visit to the Natural History Museum in London, the senior author found 16 representatives of the genus Vanniusoides collected in the Solomon Islands. They represent a new species, which lacks the tubercle on the clypeus. This structure is not characteristic of the genus but of the species Vanniusoides brevis (Poppius). A description of the new species, and redescriptions of the genus and species $V$. brevis are given below.

\section{TAXONOMY}

Subfamily Palaucorinae Carvalho, 1956

Tribe Vanniini Gorczyca, 1997

\section{GENUS VANNIUSOIDES CARVALHO \& LORENZATO, 1978}

\section{Vannius Poppius, 1909: 3, 14 (part),}

Vanniusoides: Carvalho \& Lorenzato, 1978: 127; Schuh, 1995: 39; Gorczyca, 1996a: 337, 340; 1997: 520, 537

Type species: Vannius brevis Poppius, 1909 by original designation.

\section{Differential diagnosis}

According to structure of the pretarsus and the male genitalia this genus is related to the Afrotropical genus Afrovannius Gorczyca, 1997 but differs from it in the relatively thin femora, thick setae on hemelytra and relatively long rostrum. Both genera can be distinguished from Vannius Distant by the presence of a subapical tooth on claws and characters of the genitalia.

\section{Redescription}

Characterized by the general colour pattern (Fig. 1) and the pretarsal structure. Body elongate oval, smooth, bearing long, thick setae. Head vertical, vertex slightly convex, without longitudinal sulcus, frons prominent. Clypeus distinct, eyes contiguous with pronotal collar. Antennae longer than body, contiguous with eyes, inserted on tubercles in the middle of the anterior margin of eye. First antennal segment thicker than the others, which are thin and covered with short setae.

Pronotal collar broad, enlarged in the middle, pronotum wider than long, the posterior margin bisinuate, humeral angles rounded. Mesoscutum exposed, scutellum small, flat.

Hemelytra with well developed embolium, cuneus long, almost twice as long as wide at base. Membrane well developed, with two cells.

Ostiolar peritreme small, rounded. Metafemora and metatibiae thin and noticeably long, tibiae covered with short setae and a few spines distinctly thickened distally. Tarsi two-segmented (Fig. 12), long, second segment not subdivided. Claws curved, toothed subapically, parempodia large (Figs 12-14).

\section{KEY TO THE SPECIES OF VANNIUSOIDES}

1 Head almost unicoloured, clypeus thin, with a small, distinct tubercular ventral projection ......... brevis (Poppius)

- Head yellow or red dorsally, white below the antennal tubercles, clypeus distinctly widened apically, without a tuberclar ventral projection ....... clypeatus $\mathrm{sp}$. nov.

Vanniusoides brevis (Poppius, 1909)

Vannius brevis Poppius, 1909: 15; Bergroth, 1920: 72; Carvalho, 1957: 34, 1980: 658

Vanniusoides brevis: Carvalho \& Lorenzato, 1978; Schuh, 1995: 39; Gorczyca, 1997: 539

Diagnosis. Distinguished by head colour, clypeus narrow (in frontal view) with a small but distinct tuber- 
cular ventral projection (Figs 2-3), and the structure of male genitalia.

\section{Redescription}

Male. Body length: $3.2 \mathrm{~mm}$, width: $1.2 \mathrm{~mm}$., colour pale yellow with contrasting red spots and patches. Head pale, width (in top view) $0.6 \mathrm{~mm}$, length: $0.32 \mathrm{~mm}$, height: $0.6 \mathrm{~mm}$ (in lateral view). Eyes large, red, diameter of eye: $0.2 \mathrm{~mm}$. Clypeus with a small but distinct tubercular ventral projection. First antennal segment red, paler in the apical part, covered with pale setae, thickened, length: $0.39 \mathrm{~mm}$. Second segment pale yellowish, tinged with red and weakly thickened in the apical part, length: $1.4 \mathrm{~mm}$. Third and fourth segments broken. Pronotal collar pale.

Pronotum pale with a red patch in the middle, propleura reddish. Length of pronotum: $0.35 \mathrm{~mm}$. Length of the anterior margin: $0.55 \mathrm{~mm}$, posterior margin: $1.32 \mathrm{~mm}$., lateral margins: $0.32 \mathrm{~mm}$. Mesoscutum and scutellum pale, length of scutellum $0.4 \mathrm{~mm}$ (excluding mesoscutum).

Hemelytra pale with two large red patches, the apical part of clavus red, the rest pale, obscure, embolium wide, pale, with a longitudinal row of small red patches. Cuneus pale with a red patch in the middle. Membrane and venation pale.

Legs pale, reddish in places, covered with short setae. Metafemora reddish in the apical part, tarsi pale.

Aedeagus membranous, with spines surrounding secondary gonopore, parameres small, thin (Carvalho \& Lorenzato, 1978, Figs 23-25).

Female smaller than male (according to Carvalho \& Lorenzato, 1978), body length $2.50 \mathrm{~mm}$, width $0.90 \mathrm{~mm}$.

Remarks. The holotype (female) deposited in the Hungarian Museum of Natural History is badly damaged and it is virtually impossible to measure it precisely. Other females were not available. Thus, measurements of females are those of Carvalho \& Lorenzato (1978).

Type material examined. Holotype, female: New Guinea: Simbang, Huon-Golf, Biro, 1898 (Hungarian Natural History Museum, Budapest, Hungary).

Other material examined. One male: New Guinea: NE., Arnok, 169 m. Jan 6, 1960; T.C. Maa collector; Compared with Type by Carvalho 197 . [red label]; Vanniusoides brevis (Popp.), det. J. C. M. Carvalho. (Hungarian Natural History Museum, Budapest, Hungary); one male: New Guinea (NE): Maprik, 160 m., Oct. 15, 1957, J. L. Gressitt Collector; Vanniusoides brevis (Popp.), Det. J. C. M. Carvalho (Department of Entomology Collection, Bernice P. Bishop Museum, Honolulu, HI USA); one male: New Guinea: NE, Amok 165 m, Jan 6. 1970 [handwritten]; T. C. Maa colector [handwritten]; Vanniusoides brevis (Popp.) [handwritten], Det. J. C. M. Carvalho (Department of Entomology Collection, Bernice P. Bishop Museum, Honolulu, HI USA).

Distribution. Papua New Guinea.

\section{Vanniusoides clypeatus sp. nov.}

Diagnosis. This species can be distinguished by the flat and widened clypeus (Figs 4-5), colouration of the head and structure of the male genitalia.

Etymology. Named after its characteristic clypeus.

\section{Description}

Female. Colour pattern on hemelytra almost identical (Fig. 1) with that of Vanniusoides brevis (Poppius), length of the body $2.88-2.98 \mathrm{~mm}$, width $1.0-1.10 \mathrm{~mm}$. Head dark yellow, frons yellow, sometimes darkened and tinged with red, below the antennal tubercles white. Clypeus white, widened apically (Fig. 4), mandibular plates white. Width of head 0.50-0.54 mm, length (in top view) $0.28-0.30 \mathrm{~mm}$, diameter of eye $0.14-0.16 \mathrm{~mm}$. Length of the antennal segments in mm: $0.30-0.32$ : 1.25-1.38: 1.87-1.90: 2.0 (?). Rostrum relatively short, hardly reaching beyond metacoxae, yellow or dark yellow, sometimes tinged with red.

Pronotal collar broad, yellow with red patches. Pronotum with a large red patch in the middle (Fig. 1), length of pronotum (excluding pronotal collar) $0.25 \mathrm{~mm}$, length of the anterior margin $0.48 \mathrm{~mm}$, lateral margins $0.30 \mathrm{~mm}$, posterior margin $0.80-0.90 \mathrm{~mm}$. Mesoscutum and scutellum uniformly pale.

Hemelytra yellow with large red patches (Fig. 1), covered with thick dark setae. Membrane pale to grey, vena-

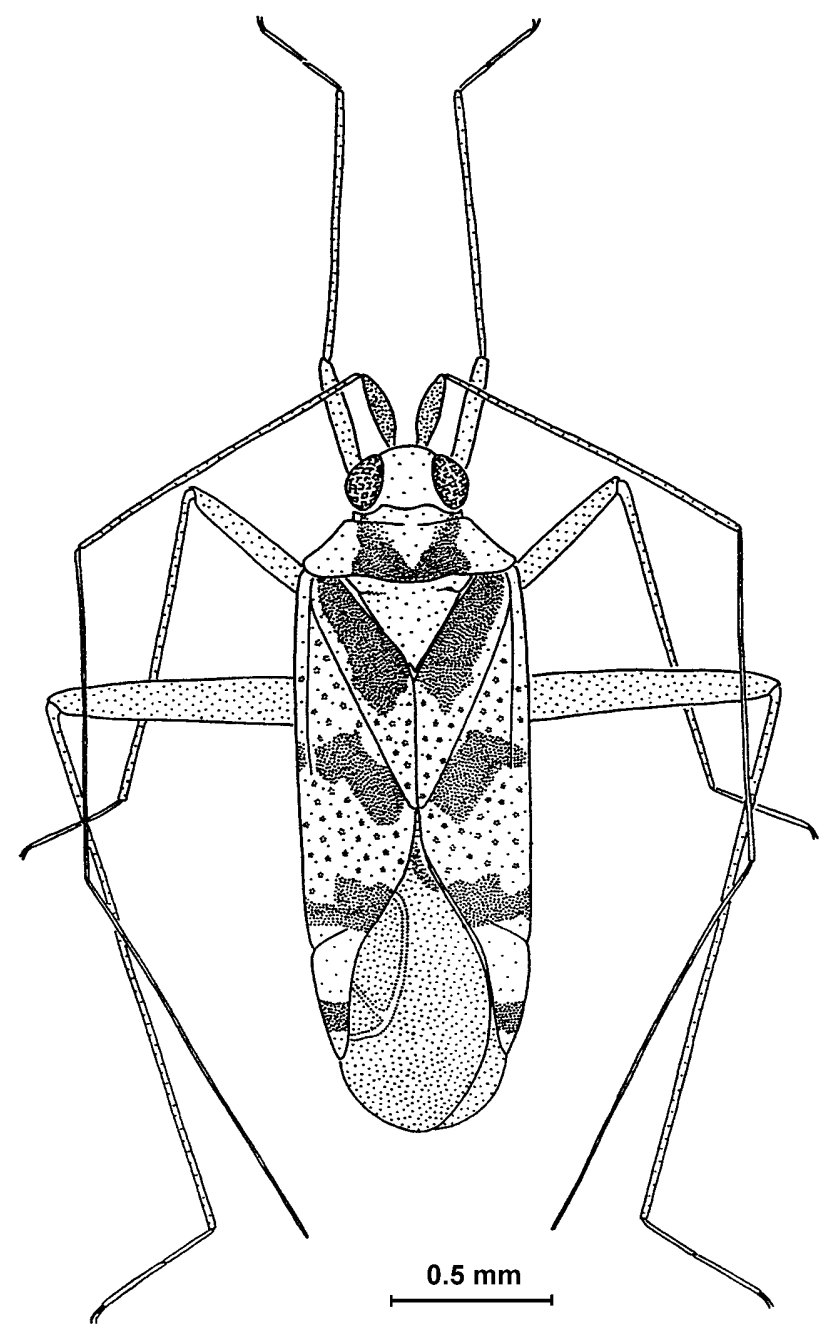

Fig. 1. - Vanniusoides clypeatus sp. nov., paratype, dorsal habitus. 


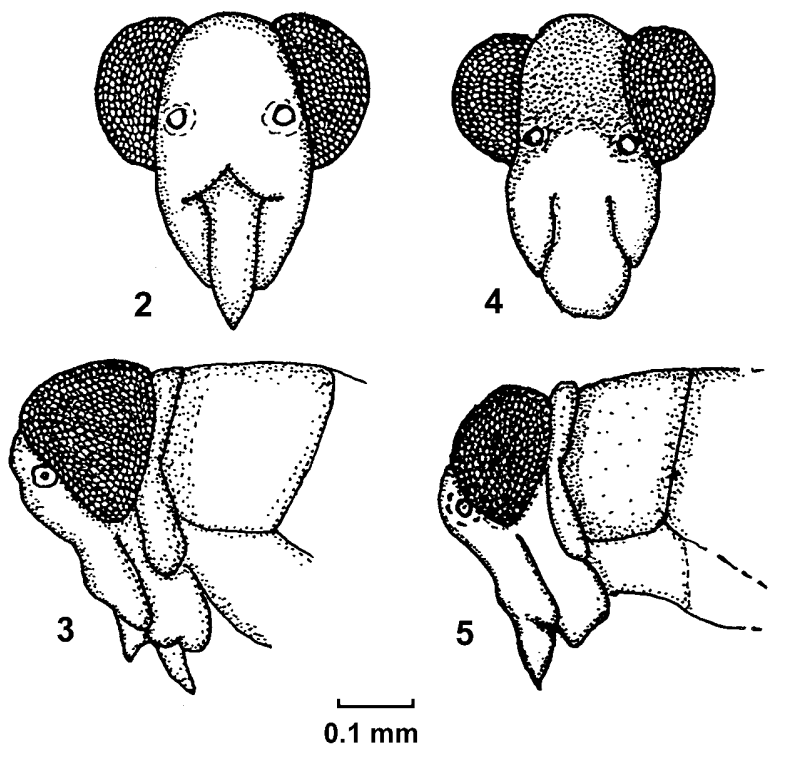

Figs 2-5: Frontal and lateral views of heads of Vanniusoides spp; 2,3 - V. brevis Poppius); 4,5 - V. clypeatus sp. nov.

tion distinct, yellow or pale, minor cell relatively large (Fig. 1).

Underside of the body yellow with red patches, legs usually yellow, sometimes darkened and tinged with red, only metafemora dark brown with red bands and patches.

Male similar to female but smaller, body length 2.37-2.40 mm, width of the body $0.45 \mathrm{~mm}$, width of head $0.45 \mathrm{~mm}$, length of head in top view $0.27 \mathrm{~mm}$, diameter of eye $0.15 \mathrm{~mm}$. Length of the antennal segments in $\mathrm{mm}$ : $0.25-0.30: 1.12-1.20: 1.32: 1.62-1.65$. Length of pronotum (excluding pronotal collar) $0.17-0.18 \mathrm{~mm}$, length of the anterior margin $0.40 \mathrm{~mm}$, lateral margins $0.22-0.25$ $\mathrm{mm}$, posterior margin $0.72-0.76 \mathrm{~mm}$.

The shape of the genital capsule triangular (Figs 6-7), parameres thin, flat, curved (Figs 8-11), theca weakly sclerotized, transparent. Vesica present, with inflatable folded lobes lacking minute teeth (Figs 15-16). One folded lobe possesses two sclerotized appendages while in $V$. brevis, judging by drawings in Carvalho \& Lorenzato (1978), all inflatable folded lobes of vesica except one armed with minute teeth apically, sclerotized appendages absent. Ductus seminis outside vesica rather wide and well sclerotized and invisible inside vesica (Fig. 15). In all probability it nearly reaches the middle of vesica but possesses very thin, practically invisible walls and opening of secondary gonopore.

Type material. Holotype (female): Solomon Islands: Kolombangara, Iml inland. Camp. 1., Kolombara R. 6. ix. 65, Roy. Soc. Exped., B. M. 1966-1; paratype (male): same data as holotype; paratypes (six females and eight males): vac. collector. flood refuse and between stones, river bank; Solomon Islands: Kolombangara, Iml. inland. from Kuzi camp. 1., 7. ix. 65., Kolombara R.; Roy. Soc. Exped., Brit. Mus. 1966-1. Five paratypes are deposited in the collection of the Department of Zoology, University of Silesia, Katowice, the holotype and ten paratypes in the Natural History Museum, London.

Distribution. The Solomon Islands: Kolombangara.

\section{BIOLOGICAL DATA}

There is little information on the biology of the species of the tribe Vanniini. Some species have been described on the basis of single specimens and some are known only from light trap material. In a few cases (Gorczyca, 1997) the notes on the labels on pinned specimens indicate that they live on fungi e. g. Paracylapus lestoni (Gorczyca, 1996b). Others have been found on fruit and flowers e. g. Vannius rubrovittatus Distant, V. oculatus Carvalho (Gorczyca, 1997). There is no information on the biology of Vanniusoides brevis (Poppius) and there is also no information on how the specimens were collected. The representatives of Vanniusoides clypeatus were caught with a vacuum collector on a river bank, in flood refuse and between stones. These are unusual sites for the species of this group, being more typical of the family Saldidae.
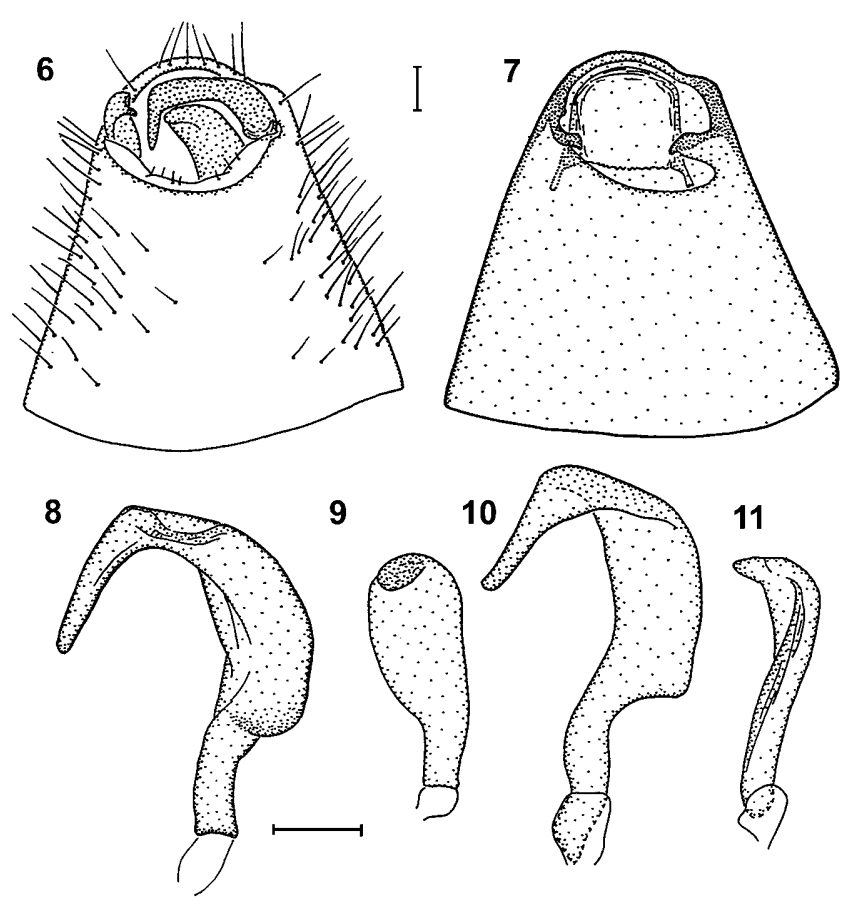

9
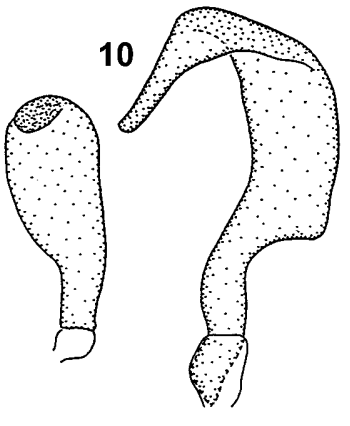

11

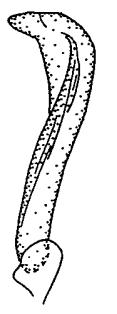

12
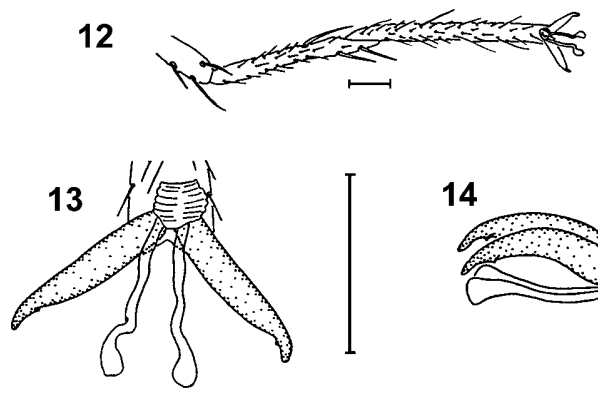

14

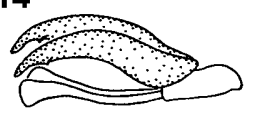

Figs 6-14: Vanniusoides clypeatus sp. nov., male, paratype; 6 - genital segment in a dorsal view; 7 - genital segment with separated aedeagus and claspers; 8,10 - left clasper; 9,11 - right clasper; 12 - metatarsus; 13,14 - pretarsus. All scale bars equal $0.05 \mathrm{~mm}$. 


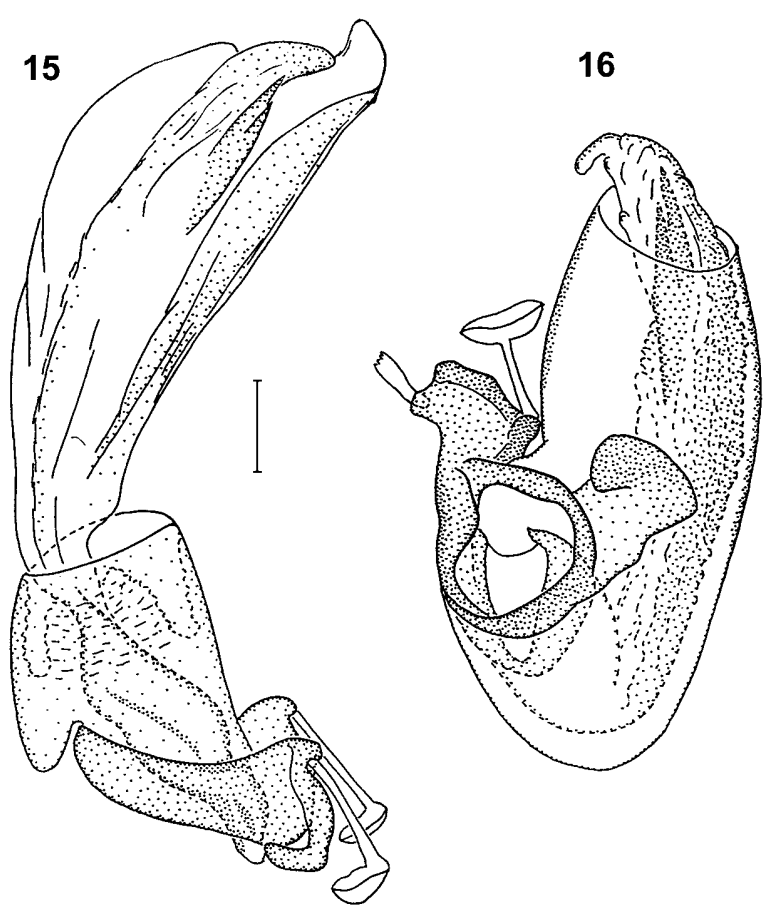

Figs 15-16: Vanniusoides clypeatus sp. nov., male, paratype. 15 - erect aedeagus; 16 - aedeagus in repose. The scale bar equal to $0.05 \mathrm{~mm}$.

ACKNOWLEDGEMENTS. We would like to express our sincere thanks to Karin Kami and Gordon Nishida (Department of Entomology Collection, Bernice P. Bishop Museum, Honolulu, HI USA), Mick Webb (Natural History Museum, London, GB) and
Thámas Vásárhelyi (Hungarian Natural History Museum, Budapest, Hungary) for the loan of specimens. The work was partly founded by the program "Russian Universities" (project No. 3917).

\section{REFERENCES}

Bergroth E. 1920: List of the Cylapinae (Hem., Miridae) with description of new Philippine forms. Ann. Soc. Entomol. Belg. 60: $67-83$.

Carvalho J.C.M. 1956: Insects of Micronesia: Miridae. Insects Micronesia 7: 1-100.

Carvalho J.C.M. 1957: Catalogue of the Miridae of the World. Part I. Subfamilies Cylapinae, Deraeocorinae and Bryocorinae. Arq. Mus. Nac., (Rio de Janeiro) 44: 1-158.

Carvalho J.C.M. 1980: Analecta Miridologica, IV: Observations on type specimen in the National Museum of Natural History, Budapest, Hungary (Hemiptera, Miridae). Rev. Brasil. Biol. 40: 649-658.

Carvalho J.C.M. \& Lorenzato L.M. 1978: The Cylapinae of Papua New Guinea. Rev. Brasil. Biol. 38: 121-149.

GorCZYCA J. 1996a: A new species of Vannius Distant, 1883 from Madagascar (Heteroptera, Miridae). Genus 7: 337-340.

GorCzYCA J. 1996b: Pseudovannius lestoni gen. n. sp. n. from Ghana (Heteroptera: Miridae). Genus 7: 341-346.

GorCZYCA J. 1997: Revision of the Vannius-complex and its subfamily placement (Hemiptera: Heteroptera: Miridae). Genus 8: 517-553.

Popprus B. 1909: Zur Kenntnis der Miriden-Unterfamilie Cylapina Reut. Acta Soc. Sci. Fenn. 37: 46 pp.

Schun R.T. 1995: Plant Bugs of the World (Insecta: Heteroptera: Miridae), Systematic Catalog, Distributions, Host List and Bibliography. New York Entomological Society, New York, xii +1329 pp.

Received April 4, 2000; accepted June 12, 2000 